\title{
A TÉRSÉGI FEJLŐDÉS TÁRSADALMI KIHÍVÁSAI (EGY ÚJ KUTATÓCSOPORT FELADATAI)
}

(Social Challenges of Spatial Development Missions of a Research Group)

\section{SZIRMAI VIKTÓRIA}

Kulcsszavak:

Közép-dunántúli régió globalizáciỏ versenykẻpesség urbanizáció tärsadalmi konfliktusok

Ebben a tanulmányban a térségi fejlôdésnek azokat a társadalmi kihivásait, illetve kutatási problémáit foglaljuk össze, amelyek az elsõ év helyzetfeltáró munkája eredményeként fogalmazódtak meg, amelyek komplex tudományos igényü viesgálata Fejér megye és Székesfehérvár megyei jogú város számára is fontosak, és amelyekkel kapcsolatban feltártak konkrét segítséget adhatnak a térségi fejlödés akadályainak elháritásában, a kezelés eszközeinek a kidolgozásában, és amelyek esetében a konkrét kutatás is megindult.

\section{Bevezetés}

A 2000. szeptember 1-jén megalakult MTA RKK NYUTI Közép-dunántúli Kutatócsoport munkáját több hosszú távú stratégiai kutatási cél határozta meg. Ezek közül a legfontosabbak Székesfehérvár megyei jogú város, illetve Fejér megye, a Közép-dunántúli régió területi, területfejlesztési, gazdasági, társadalmi, környezeti folyamatainak, problémáinak, konfliktusainak, a vonatkozó tendenciáknak tudományos igényú feltárása, a regionális, a megyei, a városi fejlesztési döntések településtudományi hátterének a megalapozása, a Közép-dunántúli régió szerveződéseit meghatározó gazdasági, társadalmi folyamatok elemzése, a regionális szervezỏdés támogatása, a feltárt ismeretek és eredmények hozzáférhetőségének biztosítása az eredmények gyakorlati alkalmazásában érdekelt helyi, megyei, illetve regionális partnerek és a tudományos szereplök számára, a város, a megye, a régió és a nemzetközi, illetve hazai szaktudományos kőzélet kapcsolatainak gazdagítása, tudományos fórumok, konferenciák szervezése. Végül, de nem utolsósorban a kutatócsoport hazai és nemzetkőzi szakmai tekintélyének megalapozása.

Az eltelt időszak minden feladat esetén elörelépést hozott, a csoport minöségi munkájához nélkülözhetetlen infrastrukturális feltételeket megteremtettük, a hazai és a nemzetközi szakmai kapcsolataink folyamatosan bỏvülnek, számos konferenciát, tudományos vitaülést rendeztünk, rangos folyóiratokban publikálunk.

A kutatómunka is megkezdödött, korábbi vizsgálati eredmények újraelemzése, az állandó sajtófigyelés, a terepbejárás és a saját, új empirikus vizsgálataink eredményeként egyre több a térségi ismeretünk. 
Szirmai Viktória : A térségi fejlődés társadalmi kihívásai (Egy új kutatócsoport feladatai).

Tér és Társadalom 15. évf. 2001/2. 173-182. p.

\section{A térség jövöjének problematikája}

A térséget elemzỏ dokumentációból, statisztikai és egyéb vizsgálati eredményekböl is nyilvánvaló, hogy a hazai modernizáció, a rendszerváltást követő gazdasági és társadalmi átalakulás Fejér megye és Székesfehérvár fejlódési, fejlesztési lehetóségeinek kibővülését okozta. Fejér megye gazdasági bázisa szerint a kilencvenes évek közepére megtörtént a gazdaság és a társadalom átstrukturálódása, kialakultak az új növekedési irányok. Közismert, hogy az átalakulás - a külföldi tőkebefektetésekre alapozott gazdasági szerkezetváltás eredményeként - különösen Székesfehérvár esetében volt sikeres. A székesfehérvári modell azóta is számos település számára kínálja a gazdasági és társadalmi problémák megoldásának útját, követendỏ példaként jelenik meg.

A korábbi vizsgálati anyagokból kiderulnek azonban árnyoldalalak is, a területi különbségek mélyưlése, egyes kistérségek gazdasági, társadalmi hátrányai, a régió, a megye, Székesfehérvár jelentős belsó fejlettségi differenciáltságai.

A hazai regionális kutatások alapján is ismert, hogy a magyarországi gazdasági átmenet térségekként és településekként igen eltérö módon zajlik. Részben az örökölt gazdasági (és társadalmi) fejlettségbeli sajátosságok, részben a piacgazdaság kialakulásának eltérései miatt. A szociológiai kutatások pedig az átalakulás társadalmi következményeit, a gazdasági szerkezetváltás területi és egyéb előnyeit élvezỏ társadalmi csoportokat, az elönyökből kimaradó hátrányokkal sújtott rétegek problematikáját tárták fel. A szóban forgó térség esetében azonban az utóbbi problémák kevésbé feltártak, amelyek részletes vizsgálatára már csak azért is szuukség van, mert támogató társadalmi erók nélkül a térségi fejlódést nem lehet megvalósítani.

A csoport munkáját megalapozó tudományos koncepció szerint a közeljövő elemzéseinek mindenekelött arra kell választ adniuk, hogy a már lejátszódott folyamatok milyen hatással lehetnek a jövőbeni átalakulásokra, milyen új folyamatok érzékelhetóek, mi jellemzi a változások keretében kibontakozó területi, társadalmi trendeket, a trendekhez kapcsolódó társadalmi, gazdasági, környezetvédelmi és egyéb feszültségeket. Az eddigi kutatások még nem tárták fel teljes körúen, hogy a polgári átmenet, a piaci társadalom kiépủlése, a globális urbanizáció mai tendenciái, a nemzetközi gazdasági és társadalmi hatások, a gazdasági globalizáció, az európai integráció milyen ellentmondásos folyamatokat hoztak létre a közép-dunántúli térszerkezetben. Mi jellemző a területi társadalmi egyenlötlenségek modern struktúráira, a város és a vidék részben újraszerveződőtt, részben enyhült egyenlötlenségeire. Az új folyamatok milyen jövöbeni forgatókönyveket ígérnek, és mi ebben a társadalmi szereplök felelóssége és lehetősége. 
Szirmai Viktória : A térségi fejlődés társadalmi kihívásai (Egy új kutatócsoport feladatai).

Tér és Társadalom 15. évf. 2001/2. 173-182. p.

TÉT XV. évf. 2001 @ 2

A térségi fejlődés...

175

\section{A globalizáció problematikája}

A nemzetközi és a hazai szakirodalmak szerint a magyarországi gazdasági átmenet (a helyi sajátosságok mellett) alapvetően két nagy gazdaságfejlesztési stratégia alapján bontakozott ki. Az elsö esetben a helyi intézmények, kőzte az önkormányzatok is arra törekszenek, hogy kulső magántőkét, elsősorban a kulfőldi tőkebefektetőket vonjanak be a térségi, települési gazdaságba. A második esetben a helyi intézmények a legkülönbözőbb, kőzvetett vagy kőzvetlen központi támogatások alapján valósitják meg a gazdasági szerkezetváltást (Keune 2001, 12).

A kialakult gazdaságfejlesztési stratégiákat több tényezó is magyarázza, mindenekelótt kényszerpályák, továbbá értékpreferenciák, eltérő problémakezelési módok, ideológiák, szakma kultúrák, intézményi és társadalmi érdekeltségek. A kényszerpályákra utal, hogy a települések, térségek történeti adottságaik, infrastrukturális jellegzetességeik, a hazai és a térségi töke megjelenése, a fôldrajzi helyzet, a munkaerö-piaci jellegzetességei alapján (voltak) képesek „dőnteni” arról, hogy milyen gazdaságfejlesztési stratégiát kövessenek. A területi kutatások szerint a jelzettek szempontjából kedvezőbb adottságú települések, térségek inkább az első változat szerint indultak fejlödésnek, míg a kedvezőtlenebb helyzetben lévőknek maradt a második változat (sokszor annak is csak a reménye).

A szakmai érvek talán nagyobb része állítja, hogy a külfơldi tơke bevonására épitő gazdaságfejlesztési stratégia a siker, a gyors gazdasági átalakulás, a társadalmi fejlődés, a globális gazdaságba, illetve az európai városhálózatba történó integráció útja (Keune 2001, 13). Tegyluk hozzá, hogy társadalmi érdekek sokasága támogatta ezt a stratégiát. A rendszerváltás után az alacsonyabb társadalmi státuszú társadalmi csoportok számára a legfontosabb érték a munkaalkalmak biztosítása volt. A globális gazdasági hatások, a multinacionális vállalatok (közte Fejér megyei) megjelenése a munkanélkuliség problémáinak gyors kezelését adták. A középosztálybeliek támogatását a fogyasztási igények, az ehhez szükséges magas jövedelem és termék-kínálat hozta. A régi és az új elitcsoportok pedig szakmai tudásukból, mindennapi kultúrájukból (nyelvismeretükből) adódóan, életforma elvárásaik alapján is kiemelten a külfooldi tỏke bevonására építő gazdaságfejlesztési stratégiákban, illetve a gyors fejlodés akkor konkrétan meglévő feltételeiben voltak érdekeltek.

Az állam megváltozott szerepei következtében a területfejlesztés decentralizációja során kialakult új helyi intézményeknek, az önkormányzatoknak is többnyire hasonlóak voltak az érdekei, a helyi tơkehiány, a polgárosodás lassúsága, a szúkő̀s önkormányzati erőforrások viszonyai között a globális, piaci hatások érvényesülése adta a viszonylagos mozgás és fuggetlenedés lehetöségét, legalábbis a korábbi állami függésektôl. Mindezek együttesen eredményezték a globalizációra, a kủlfơldi tőkebefektetésekre épưlő gazdaságfejlesztési stratégiák szinte kőzkonszenzusra alapozott elfogadottságát.

Miközben egyre többen vitatják ezt a stratégiát, a szakmai érvek is sokasodnak a szakirodalomban, a külföldi tơkebefektetések negatív hatásai és konfliktusai láttán 
Szirmai Viktória : A térségi fejlődés társadalmi kihívásai (Egy új kutatócsoport feladatai).

Tér és Társadalom 15. évf. 2001/2. 173-182. p.

176 Szirmai Viktória

TÉT XV. évf. $2001 \mathbf{\square} 2$

(Makó-Ellingstad 1999). Az ellenérzések és vita érvek részben gazdasági jellegủek. Az ellenérzéseket azok a vizsgálati eredmények adják, amelyek szerint a külföldi nagyvállalatok nem integrálódnak sem a helyi, sem pedig a térségi gazdaságba (illetve csak igen kis szegmentjét integrálják annak). Nem igazán dinamizálják a térség munkaerőpiacát, csupán az olcsó és a szakképzetlen munkaerőt használják fel. $\mathrm{S}$ ezt a civil társadalmak, a szakszervezetek gyengesége miatt tudják megtenni (Keune 2001; Nemes Nagy 2001).

Az ellenérvek másik részét a gazdaságfejlesztési stratégia kedvezőtlen társadalmi következményei, társadalmi konfliktusai, a globalizációban szerveződő társadalmi egyenlőtlenségek, a gazdaság fejlődését is akadályozó társadalmi, környezeti feszültségek váltják ki.

A Közép-dunántúli régió, Fejér megye, Székesfehérvár jövőbeni fejlődése szempontjából is fontos kutatási problematika a globális gazdaság térségi hatásmechanizmusainak a feltárása, a globális és a lokális gazdaság viszonya, közte a multinacionális vállalatok térségben elfoglalt helye és szerepe. A nemzetközi szakirodalmak vonatkozó eredményei, de a külfơldi tőkebefektetésekre alapozott gazdaság és térségfejlesztési stratégiák hatásait vizsgáló hazai esettanulmányok is a fưggés problematikájára, a globális tényezők, a nemzetközi piac és gazdaság igényei szerint alakuló folyamatokra mutatnak rá. A függések az érintett térségek vezetőinek és társadalmainak a beállítottságaiban, a félelmeikben is megmutatkoznak, a „mi lesz, ha elmennek?” - kérdésében.

Egyre több szakértỏ veti fel, hogy a térségek hosszú távú, egyben autonómabb fejlödését csak a globális és a lokális gazdaság egyensúlya, a multinacionális vállalatok, illetve a kis- és középvállalkozók érdekeit is érvényesíteni képes gazdaságfejlesztési stratégiák képesek megteremteni. Csak ez biztosíthatja a gazdasági előnyök területi kiterjedését, a kedvezö hatásoknak kitett társadalmi csoportok számának a növelését, a gazdasági és a társadalmi fejlódés összhangját, az érintett társadalmak életminőségének javulását.

A globális gazdaság térségi összefüggéseinek a feltárása érdekében a multinacionális vállalatok gazdasági és társadalmi hatásait a kutatócsoport 2001ben kezdte el vizsgálni. A több éves kutatás a multinacionális cégek problematikáját több metszetben kívánja feltárni. Ezért egyrészt a globális folyamatoknak a multinacionális cégek jelenlétén keresztül érvényesülő hatásait, a globális gazdasági érdekeknek a térség gazdasági, társadalmi és térszerkezeti fejlődésére gyakorolt következményeit és konfliktusait vizsgálja. Másrészt a térség globális gazdaságra gyakorolt hatásainak a feltárására is törekszik, többek között éppen a térségi függés és az autonómia problematika megközelítése céljából. A térség globális gazdaságra gyakorolt hatásait a transznacionális cégek és a térség gazdasági, társadalmi kapcsolatrendszerein, a globális és a lokális folyamatok integrációján keresztül közelítjük.

Ez utóbbi kutatási probléma megfogalmazásakor föként arra vagyunk kíváncsiak, hogy az érintett helyi társadalmakra milyen hatással van (volt) a multinacionális cégek jelenléte. Mely térségi és társadalmi csoportok a kedvezményezettjei a 
Szirmai Viktória : A térségi fejlődés társadalmi kihívásai (Egy új kutatócsoport feladatai).

Tér és Társadalom 15. évf. 2001/2. 173-182. p.

globális gazdaság megjelenésének, kik jártak jól, kik jártak rosszul. Melyek azok a térségek, ahol a globalizáció következtében megindult a fejlödés, és mit jelent ez a fejlődés. Milyen módon változott meg a politikai, a gazdasági, a civil elit hatalmi és gazdasági súlya, melyek az egzisztenciális következmények. Az integráció szempontjából az is fontos kérdés, hogy az érintett társadalmi aktoroknak melyek voltak a globális gazdasággal kapcsolatos reményeik, elvárásaik, és ezekbő́l melyek teljesültek és melyek nem.

Feltevésủnk szerint a globális gazdaság meggyengítette a gazdasági, a politikai elit, de a középosztály egyes szakmai csoportjait is. A multinacionális vállalatok jelenléte új típusú bér és hatalmi egyenlötlenségeket, a korábbi döntéshozók kiszorultságát hozta. Nagyon sokan kényszerültek szakmaváltására, a multinacionális cégek magyar menedzsmentje szaktudásához képest alacsonyabb beosztásban, kisebb szakismereteket igénylő munkakörben dolgozik. A külföldi alkalmazottakhoz képest rosszabbak a lakás- és a lakóhelyi körülményeik, jövedelmük alacsonyabb. A tatabányai kutatásunk eredményei erre mutatnak (Szirmai-A. Gergely-Baráth-Molnár-Szépvölgyi 2001). A politikai elit lehetőségeire is ellentmondásosak a hatások. A térségi politikusok befolyását ugyan növelte, hogy a multinacionális vállalatok menedzsmentje (általában) nem vesz részt a térségi politikában, miközben az egyik legfontosabb szociális feszültséget, a munkanélkưliség veszélyeit jelentös mértékben enyhítette. A tényleges befolyásukat azonban csökkenti, hogy a térségek jövője egyelöre a transznacionális cégcsoportok mai és jövőbeni stratégiájától fủgg.

A kutatás során azt is vizsgáljuk majd, hogy milyen (társadalmi, gazdasági, politikai) kapcsolatban vannak a multinacionális vállalatok a társadalmi-gazdasági térrel, a különböző társadalmi szereplökkel, így az önkormányzatokkal, a politikai pártokkal, az elit csoportokkal, a térségi gazdaság képviselöivel, a kis- és középvállalkozókkal, a helyi társadalmi közélettel. Milyen külső és belső tényezők határozzák meg ezt a kapcsolatrendszert: a globalizáció, a vállalatok nemzetközi érdekeltségei, a versenyképesség gazdasági, társadalmi faktorai, a menedzsment érdekeltségei vagy a térségi helyi folyamatok is, a térség, a város vonzó társadalmi, kulturális arculata, különböző szolgáltatások (éttermek, üzletek) vagy éppen a föváros közelsége? A kutatás arra is kiterjed, hogy a transznacionális vállalatok térségi képviselői, a külföldi és a magyar menedzsment számára a térség csak munkahelyet (piacot), vagy életteret, lakóhelyet is jelent-e?

A kutatás eddigi eredménye 2001-ben, a multinacionális vállalatok telephely. választási stratégiáját meghatározó tényezők, illetve a jövöbeni elképzeléseket és stratégiákat meghatározó szempontok vizsgálata. Az első évben a nemzetkőzi eredmények összegzésére összpontosítottunk, miközben a transznacionális cégek térségi gazdasági és társadalmi kapcsolatainak a feltárása is megkezdődött (részben kérdöíves, részben mélyinterjús módszerekkel). A kutatás részletes eredményeit Baráth, Molnár, Szépvölgyi cikke mutatja be. 
Szirmai Viktória : A térségi fejlődés társadalmi kihívásai (Egy új kutatócsoport feladatai).

Tér és Társadalom 15. évf. 2001/2. 173-182. p.

\section{A versenyképesség problematikája}

A térség központi problematikảja, hogy milyen gazdasági, társadalmi, politikai, hatalmi (érdekérvényesítési) tényezỏk biztosítják a megye, a város, a régió hosszú távú és versenyképes fejlődését, illetve, hogy milyen módon lehet Fejér megye és Székesfehérvár versenyképességén keresztül az európai integrációt, Székesfehérvár esetében az európai városok hálózatába történó integrációt is támogatni?

A kutatók számára az adott problematika többféle kérdést is felvet, részben azt, hogy milyen folyamatok okozták egyes térségek versenyképességét (sikerét, fejlődését), és milyen tényezök váltották ki más térségek esetében a versenyképesség esélyeinek romlását, a gazdasági, társadalmi leromlást, az integráció nehézségeit. A legfontosabb kérdés azonban, hogy mi a versenyképesség, a siker fogalma, melyek a föbb dimenziók, és mi a versenyképesség társadalmi tartalma. Milyen viszony van a versenyképesség, a versenypozició és az érintett társadalmi csoportok között; milyen hatással van (inkább lehet) a hosszú távú versenyképesség fenntartására a társadalmi részvétel, az érintett társadalmi és térségi szereplők kooperációja, a társadalmi érdekellentétek kezelése.

Véleményünk szerint a versenyképesség értelmezéséhez komplex megközelítésre van szükség, amely a gazdasági és a földrajzi, területi típusú megközelítések kiegészitését, a társadalmi és politikai, hatalmi összefüggések kimunkálását, az ún. humán eröforrás problematika kiszélesítését, szociológiai felfogását is feltételezi. Ezért a konkrét kutatások során fel kell tárni a versenyképesség, a siker területi szintủ problematikáját, meg kell tudni, hogy az érintett szereplők számára mit jelentenek ezek a fogalmak, mit értenek sikeren, versenyképességen. A tatabányai kistérség esetében készült vizsgálati eredmények például egyértelmüen arra utalnak, hogy az átalakulás különböző szakaszai, a kilencvenes évek válságkezelése, majd a kilencvenes évek végétöl kibontakozó fellendülés időszakai más és más értelmezését adják a folyamatoknak, társadalmi szereplökkent is eltérő a térségi siker felfogás (Szirmai-A. Gergely-Barảth-Molnár-Szépvölgyi 2001).

Az MTA RKK Közép-dunántúli Kutatócsoportja és a Friedrich Naumann Alapitvány által Székesfehérváron megrendezett „Fejlödő városi térségek” c. konferencián elhangzott elöadások egyértelmüen arra mutatnak, hogy a regionális tudományok új siker- (illetve ủj versenyképesség-) felfogása születésének vagyunk ma tanúi. Az elỏadók kivétel nélkül egyetértettek abban, hogy a siker és a versenyképesség fogalma történetileg, térségenként és társadalmi csoportonként változó, továbbá, hogy a gazdasági siker helyett egyre fontosabb a társadalmi értelemben is sikeres fejlődés felfogás.

A siker, illetve a versenyképesség komplex értelmezését alkalmaztuk egy nemzetközi kutatásban, a Programme Internationale de Cooperation Scientifique, az ún. PICS kutatás keretében, amely az MTA Szociológiai Kutatóintézet és a CNRSUniversités de Paris VIII („Dynamiques sociales et recomposition des espaces”) együttmüködẻse keretében jött létre. (A téma magyar felelőse Szirmai Viktória, a munkába a csoport fiatal kutatói is bekapcsolódtak.) A kutatás fö irányát a címe is 
Szirmai Viktória : A térségi fejlődés társadalmi kihívásai (Egy új kutatócsoport feladatai). Tér és Társadalom 15. évf. 2001/2. 173-182. p.

mutatja: „L'évolution des rapports sociaux entre espaces urbains et espaces ruraux. Mécanismes locaux et évaluation des effets de l'entrée dans l'Union Européennne de la Hongrie et de la Pologne" (A városi és a falusi terek közötti társadalmi kapcsolatok fejlödése. Az EU-ba lépes helyi társadalmi mechanizmusokra gyakorolt hatásai).

A vizsgálat kiindulópontja az volt, hogy a térségi versenyképesség a város és környéke kooperációjától, a térségi, a regionális, a város és környéke gazdasági, politikai és társadalmi együttmúkődésétől, a korábbi évtizedekben jellemzö hierarchikus viszonyok átalakulásától, a verseny és az együttmüködés új gyakorlatától is fừgg.

A kutatás eddigi eredményei szerint az európai integráció, a városok versenyében azok a térségek illetve városok vannak hosszú távon előnyös helyzetben, amelyek:

1. a rendszerváltozást követő - területileg igen differenciáltan jelentkező gazdasági, társadalmi és politikai válságot alapvetỏen megoldották, amelyek fokozatosan végrehajtották a gazdasági szerkezet átalakítását, diverzifikálását a piaci követelményeknek megfelelöen, amelyek megnövelték a térségi és a városi funkcióikat,

2. a környezetükkel, a szélesebb térségükkel szoros gazdasági, társadalmi és környezetvédelmi kapcsolatokat, egyenrangú partneri viszonyon nyugvó kooperációkat alakítanak ki, és ennek következtében a térségük (régiójuk) sokoldalú gazdasági és társadalmi centrumaivá válnak, a versenyben elért helyzetük pozitív hatásait kiterjesztik, ,igazságosan elosztják”, már csak azért is, mert a térségi, regionális eredményekröl van szó. Az európai integrációban különös jelentöségre számíthatnak a térségi, regionális szerveződések, a legkülönbözőbb pályázatok feltétele a területi együttmüködés,

3. az érintett társadalmi csoportok integrálására törekszenek, amelyek a szegényebb társadalmi csoportok problémáit kezelik, amelyek választ adnak az „underclass” problematikára, és amelyek a középosztály érdekeit és (az innovációs folyamatokban kitüntetett szerepet játszó) elit csoportok szempontjait is figyelembe veszik,

4. és a társadalmi, gazdasági, ökológiai és a területi, térségi, regionális konfliktusok feltárására, megelözésére és kezelésére is képesek (Szirmai-A. Gergely-Baráth-Molnár-Szépvölgyi 2001).

\section{A területi, társadalmi folyamatok alakulása, az urbanizáció problematikája}

Az MTA RKK NYUTI Közép-dunántúli Kutatócsoport egyik legfontosabb kutatási problematikája a területi, társadalmi folyamatok, az urbanizáció alakulása. A nemzetközi trendek alapján ismert, hogy a 20 . század globális urbanizációs folyamatai a korábbi időszakokhoz képest sokkal kedvezőtlenebb társadalmi következményekkel jártak, területi egyenlötlenségekkel, térbeli társadalmi elkülönüléssel, szegregációval, a nagyvárosi (városi) szegénység, a deviancia, a 
Szirmai Viktória : A térségi fejlődés társadalmi kihívásai (Egy új kutatócsoport feladatai).

Tér és Társadalom 15. évf. 2001/2. 173-182. p.

bủnözés nővekedésével, a természeti környezet rohamos romlásával, és az ebböl is adódó egészségkárosodással, a különbözö társadalmi csoportok közötti éles társadalmi konfliktusokkal.

A nagyvárosok (nagyvárosi régiók), de a városok különbözó típusai sem képesek a társadalmi feszültségek miatt a központi szerepeiket betölteni, a különbözö területi szintek között közvetíteni, képtelenek a globális világ, a nemzet, a régió, a térség stb. gazdasági, társadalmi, politikai központjai, az innováció motorjai lenni (nem képesek közvetíteni a különböző szintek között, így például a globális és a helyi gazdaság vagy társadalom között). A területi társadalmi egyenlőtlenségek és a belső társadalmi feszültségek akadályozzák a városok fejlódését, a gazdaság, a városi funkciók múködését, megterhelik a város társadalmi életét, komoly többletköltségekkel is járnak.

2001-ben a kutatócsoport fỏ feladata a következő év urbanizációs vizsgálatának elméleti megalapozása, a nemzetközi trendek áttekintése, az európai, illetve az amerikai urbanizációs, közte a szuburbanizációs folyamatok elemzése, a nemzetközi, a hazai és a vizsgált térségre jellemző folyamatok összevetése volt.

2002-ben az elméleti munka alapján megvizsgáljuk, hogy milyen globális urbanizációs szakaszok érzékelhetők Székesfehérvár esetében, megkezdődött-e és milyen jellegzetességekkel a szuburbanizáció folyamata, mi jellemző a gazdasági és társadalmi szuburbanizációra, milyen térségi társadalmi konfliktusokban nyilvánulnak meg az adott mechanizmusok.

A kutatás az urbanizációt, és annak egyik föbb folyamatát, a szuburbanizációt több szempontból közeliti, részben a gazdaság decentralizációját, részben a társadalmi rétegek főbb költözési irányait, a gazdasági folyamatokon túl társadalmi, politikai és területi meghatározottságokat, életmód igényeket is vizsgál. Miközben feltárja a szuburbanizáció társadalmi hatásait, kőzte konfliktusait, a környezeti ártalmak szociális vonzatait is, a térségi társadalmi szerkezet változásait, a szegregációs folyamatokat, a különbözö típusú települések, kistérségek ennek révén is megvalósuló együttmúkỏdését vagy éppen konfliktusait. A települések versenyképességére, gazdaságára gyakorolt komplex hatásokat is elemzi.

Erre azért is szükség van, mert a városi társadalmak (föként vezetők) többnyire igen negativan élik meg a szuburbanizáció folyamatát, amely a tehetósebb városi polgárok kiköltözésében, szegényebb társadalmi csoportok városközponti beáramlásában is jelentkezik. A negatív hatások mellett azonban látni kell, hogy a szuburbanizáció nemzetközi trendje hazai megnyilvánulásáról van szó, amelyet a gazdaság és az infrastruktúra, a társadalom dekoncentrálódása alapoz meg. Az európai nagyvárosok szuburbanizációs folyamata az amerikai sajátosságoktól lényegesen eltérő módon, kisebb konfliktusokkal játszódik le. Az elörelátás, a tudatos területi és várospolitikai beavatkozások esetében a szuburbanizációs problematika kezelhető, a kedvezőtlen hatások csökkenthetök. Többek között a belváros rehabilitációja segítségével is. Ezzel előbbre hozható a szuburbanizációt követỏ reurbanizáció szakasza, amely a városrehabilitáció hatására bekövetkezett dzsentrifikációt, a tehetős, polgári rétegek visszaköltơzését (esetleg a kisebb 
Szirmai Viktória : A térségi fejlődés társadalmi kihívásai (Egy új kutatócsoport feladatai). Tér és Társadalom 15. évf. 2001/2. 173-182. p.

mértékü szuburbanizációt is) jelenti. Számos európai nagyvárosban (közte például Budapesten is) a két folyamat egyidőben zajlik le, a megfelelő területi, várospolitikai koncepció alapján időben elkezdett városrehabilitáció kővetkeztében a tehetős társadalmi csoportok nem költöznek ki a városból.

\section{A társadalmi konfliktusok problematikája}

A nemzetközi szakirodalom szerint a területi folyamatok alakulása, a területi problémák megoldása, egy térség jövője, a versenyképesség és a siker döntő mértékben fủgg a gazdasági, a területi, az infrastrukturális adottságok, az innovációt generáló fejlesztési koncepciók, stratégiai jövőképek mellett a társadalmi tényezóktől, az érintett társadalmi csoportok érdekeitől, a társadalmi csoportok és szereplők formális, intézményesített vagy informálisan múködỏ érdekérvényesítỏ képességeitöl, a társadalmi részvételtől, valamint attól, hogy a területi politika, a várospolitika törekszik-e a társadalmi érdekkonfliktusok feltárására, kezelésére.

A kutatócsoport hosszú távú feladatai között ezért is kiemelten lényeges a társadalmi konfliktusok kutatása, a konfliktusszemlélet alkalmazása. Ezért a konkrét kutatások szintjén mindig törekszünk a különbözö területi szintek társadalmainak, a kủlönbözó társadalmi csoportoknak és szereplőknek a makrofolyamatokkal, a konkrét fejlesztési stratégiákkal és koncepciókkal kapcsolatos érdekeinek a feltárására, az előnyös és a hátrányos társadalmi pozíciójú népesség körének a kiderítésére.

A társadalmilag hátrányos helyzetü csoportok problematikája kulőn is centrális vizsgálati kérdés, a nagyobb városok, így Székesfehérvár, Veszprém, de Dunaújváros, Tatabánya jövője, hosszú távú versenyképessége is fưgg a szegénység-problematika feltárásától és kezelésétől is.

Kiemelt kutatási cél a különböző szintü térségek kőzéprétegei helyzetének, érdekviszonyainak a vizsgálta, a lehetséges érdekkonfliktusok felderítése részben konkrét ügyek, fejlesztési elképzelések kapcsán, részben a regionális, a megyei, a várospolitikai kapcsolatrendszerekben. A különböző szintủ térségek legmarkánsabb társadalmi csoportjait adják, így tölük alapvetơn fủgg a vizsgált területi szintek fejlődése, jelene és jövője is.

A térség jövője, a siker, a felzárkózás esélyei szempontjából mérvadó, hogy a döntéshozók mennyire látják át a társadalmi, gazdasági, területi folyamatok kedvezó és kedvezőtlen következményeit, mit tesznek a negatív hatások kivédéséért, és hogyan támogatják a pozitiv folyamatok érvényesủlését. Kutatói felfogásunk szerint ezért nélkülözhetetlen a kủlönbözỏ területi szinteken élő gazdasági, politikai és civil társadalmi elitcsoportok, a döntéseket befolyásolni képes társadalmi szereplök viszonyainak, érdekeltségeinek, jövóképének a vizsgálata is. 
Szirmai Viktória : A térségi fejlődés társadalmi kihívásai (Egy új kutatócsoport feladatai).

Tér és Társadalom 15. évf. 2001/2. 173-182. p.

182 Szirmai Viktória

TÉT XV. évf. 2001

\section{Irodalom}

Enyedi Gy. (2000) Globalizáció és a magyar területi fejlödés. - Tér és Társadalom. 1. 1-10. o. Innovative Policies for Sustainable Urban Development. The Écological City. (1996) Paris, Organisation for Economic Co-operation and Development.

Keune M. (2001) Helyi fejlödés, intézmények és konfliktusok a poszt-szocialista Magyarországon: áttekintés. - Keune M.-Nemes Nagy J. (szerk.) Helyi fejlödés, intézmények és konfliktusok a magyarországi átmenetben. Budapest, ELTE Regionális Földrajzi Tanszék. 7-23. o.

Major trends characterizing human settlements development in the ECE region. (1998) New York and Geneva, Economic Commission for Europe United Nations.

Makó Cs.-Ellingstad M.(1999) Globalizáció, közvetlen külfôldi tőkebefektetések és a vezetói gyakorlat modernizációja. - Szociológiai Szemle. 4. 40-58. o.

Nemes Nagy J. (2001) Az ezredvég regionális folyamatai Magyarországon: átfogó átalakulás-egyedi fejlödési pályák. - Keune M.-Nemes Nagy J. (szerk.) Helyi fejlödés, intézmények és konfliktusok a magyarországi átmenetben. Budapest, ELTE Regionális Földrajzi Tanszék. 23-35. o.

Sassen, S. (2000) New Frontiers Facing Urban Sociology at the Millennium. - The British Journal of Sociology. January-March, 143-161. 0.

Szirmai V.-A.Gergely A.-Baráth G.-Molnár B.-Szépvölgyi Á. (2001) Tatabánya és térsége (Tata és Oroszlány) társadalmi gazdasági kapcsolatrendszerei. Budapest, MTA Szociológiai Kutatóintézet. Kutatási zárótanulmány.

Territorial Development Urban Policy in Germany, Towards Sustainable Urban Development. (1999) Paris, OECD.

Wilheim, J. (1996) Introduction, les problémes de la ville dans une periode de transition.-Revue internationale des sciesnes sociales. Mars, 147. 0.

\section{SOCIAL CHALLENGES OF SPATIAL DEVELOPMENT - MISSIONS OF A RESEARCH GROUP VIKTÓRIA SZIRMAI}

The mission of Central Transdanubian Research Group (of HAS CRS WHRI) established on $1^{\text {st }}$ September, 2000 was determined by several long-term strategic research aim. The most important ones of these are the research of spatial, regional development, economic, social and environmental processes, problems, conflicts and future trends of Székesfehérvár county ranked city, Fejér county and the Central Transdanubian region; the establishment of the science background for development decisions in regional, county and city level; the analysis of socio-economic processes determining the organisations of Central Transdanubia; the support of these organisations; ensuring the availability of the main research results to the local, county level, regional partners to put it into practice and to scientific actors; the enrichment of relationships between the city, the county, the region and the international and the Hungarian academic public life; the organisation of academic forums and conferences. And last but not least the establishment of the Hungarian and international professional prestige of the research group. 